\title{
COVID-19 TESTING: ESSENTIAL FOR TRACKING INFECTION AND HELPING AUTHORITY TO OVERCOME THE CHALLENGES OF SPREAD
}

Rano Mal Piryani ${ }^{1{ }^{1}}{ }$, Suneel Piryani ${ }^{2}$, Shomeeta Piryani ${ }^{3}$, Ganesh Dangal ${ }^{4}$, Muzaherul Huq ${ }^{5}$, Dhana Ratna Shakya ${ }^{6}$

${ }^{1}$ Department of Internal Medicine, Universal College of Medical Sciences, Bhairahawa, Nepal ${ }^{2}$ Public Health Consultant, Karachi, Pakistan

${ }^{3}$ Memon Hospital, Karachi, Pakistan

${ }^{4}$ Department of Obstetrics and Gynecology, Kathmandu Model Hospital, Nepal

${ }^{5}$ Former Regional Advisor, WHO SEARO, Bangladesh

${ }^{6}$ Department of Psychiatry, B. P. Koirala Institute of Health Sciences, Dharan, Nepal

\begin{abstract}
Received: 31 May, 2020
Accepted: 9 Jun, 2020

Published: 25 Jun, 2020

Key words: Antibody Test; COVID-19; Infection; Polymerase chain reaction; Testing; Transmission.

*Correspondence to: Rano Mal Piryani, Department of Internal Medicine, Universal College of Medical Sciences, Bhairahawa, Nepal.

Email: rano.piryani@gmail.com

DOI:https://doi.org/10.3126/jcmc.v10i2.29683

Citation

Piryani RM, Piryani S, Piryani S, Dangal G, Huq M, Shakya DR. COVID-19 testing: Essential for tracking infection and helping authority to overcome the challenges of spread.Journal of Chitwan Medical College.2020;10(32):90-92.

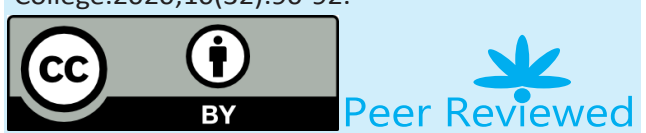

INTRODUCTION

As of June 07, 2020 (05.12 GMT); COVID-19 has already affected 213 countries and territories and 2 international conveyances around the world; around 7 million new cases and more than 0.4 million deaths have been reported. ${ }^{1}$ COVID-19 is caused by a novel Coronavirus SARS-CoV-2, an outbreak of viral pneumonia centered on Wuhan, Hubei, China reported in January 2020. ${ }^{1}$ There were two other outbreaks due to Coronavirus in recent past; one is Middle East Respiratory Syndrome (MERS) and another Severe Acute Respiratory Syndrome (SARS). MERS caused by MERS-CoV is a viral respiratory illness first reported in Saudi Arabia in 2012. SARS caused by SARS-CoV, a severe viral respiratory illness reported first in Asia in February 2003..$^{2-5}$

All these three diseases are transmitted from close person to person contact. ${ }^{3}$ Human-to-human transmission of SARS-CoV-2 (COVID-19) have been occurring till date mainly between family members and also to relatives, friends, coworkers or healthcare staff who intimately contacted with symptomatic patient or asymptomatic cases or carriers during the incubation pe- riod. However, the transmission of SARS-CoV and MERS-CoV is reported to have occurred mainly through nosocomial transmission. ${ }^{4-5}$ COVID-19 spreads much faster than MERS and SARS. For first 1000 people to get infected with MERS took 903 days, SARS 130 days and COVID-19 took only 48 days (in China). ${ }^{1,6}$ So far, there has been no effective vaccine available for prevention, no efficacious drugs to treat and no drugs for prophylaxis purpose for the COVID-19.7

\section{COVID-19 Testing: essential for tracking infection}

In an epidemic or pandemic of infectious diseases like COVID-19, testing is essential as to see who, what, where, when, why and how many people are infected by one COVID-19 patient. If there is poor testing, then most of the infected people remain undetected and can spread the virus to hundreds of the people in contact, so, the infected people could not be isolated and contacts could not be traced and quarantined. Hence, the transmission will not be limited and the cycle of transmission continues. If there is quality assured diagnostic testing along with adequate isloation/quarantine, then the spread could be limited. There are two types of tests available for COVID-19: 
test directly detecting viral ribonucleic acid (RNA) from swabs of nose and throat, and tests for detection of antibodies from blood sample (Table 1). Test performance is also tied to disease prevalence. $^{9}$

\section{Table 1: Comparison of lab tests for detection of (SARS-CoV-2, COVID-19) ${ }^{8-12}$}

\begin{tabular}{|l|l|l|l|}
\hline \multirow{2}{*}{ Test } & Tests for antibodies\# & \multicolumn{2}{|l|}{ Tests directly detecting viral ribonucleic acid RNA } \\
\cline { 3 - 4 } Version & RT-PCR* & NAAT** \\
\hline Sample & Blood & Swabs & Swabs \\
\hline Time & $\begin{array}{l}\text { Rapid: } 20 \text { minutes (Rapid Antibody } \\
\text { Test-RDT) }\end{array}$ & 6 hours & One hour \\
\hline Cost & Low cost & Costly & Moderate cost \\
\hline Detection & After six to seven days of infection ${ }^{10}$ & After infection with virus & After infection with virus \\
\hline Approval & FDA** Recently approved & Currently being used & FDA*** Recently approved $^{* *}$ \\
\hline Lab \& Staff & Staff just need orientation & $\begin{array}{l}\text { Trained staff and approved lab } \\
\text { required }\end{array}$ & Staff need orientation \\
\hline Report accuracy & $\begin{array}{l}\text { False negative report in early stages } \\
\text { of infection, with high infectivity. } \\
\text { Good for later stage. }\end{array}$ & $\begin{array}{l}\text { Highly specific. 99\% specificity and } \\
\text { sensitivity vary between 71-98\%. } 8,9\end{array}$ & $\begin{array}{l}\text { Comparably specific as RT-PCR } \\
\text { and sensitivity around } 80 \%{ }^{9}\end{array}$ \\
\hline
\end{tabular}

*RT-PCR: Reverse transcriptase polymerase chain reaction,

**NAAT: Nucleic acid amplification testing

***FDA: Federal Drug Agency (USA), \# other countries have developed this type of test.

If antibody detection tests are used, then antibodies will be detected in patient's serum after 6-7 days of infection ${ }^{10}$; by that time, patient might have already infected so many other people. The minimum incubation period of COVID-19 is 3 days while median 5-6 days. ${ }^{1}$ Patient remains asymptomatic during that period and keeps on infecting people. ${ }^{1}$ Antibody tests are commonly used to test for exposure to the viruses. These tests could help disclose people who have been exposed to the virus. ${ }^{11-13}$ They may also provide information regarding prevalence of infection. ${ }^{11-13} \mathrm{gM}$ antibodies are detected after six-seven days of infection indicating recent infection; these antibodies are short-lived. While IgG remains in the serum but for how long and other details about its protective effect is yet to be known. ${ }^{14}$

The World Health Organization (WHO) has recommended a policy of widespread testing. But the policies about lab testing for diagnosis around the world vary and there seem to be opinions in support of the different approaches- largely due to: suppliesshortages and priorities, stage of epidemic, financial constraints, etc. ${ }^{15}$

Currently RT-PCR is recommended for diagnosis of COVID-19 and antibody testing is generally recommended for public health surveillance purpose. ${ }^{16,17}$

National Testing Guidelines for COVID-19 approved by Ministry of Health and Population Welfare, Government of Nepal on June 2, 2020 recommends RT-PCR will be used for diagnostic purpose while all serology tests including the Rapid tests can be used for surveillance and/or research purpose and for screening purpose during discharge from the quarantine. ${ }^{18}$

Weinstein et al have put forward four perspectives with regard to understanding of SARS-CoV-2 antibodies; 1) presence of antibodies in infected population is known, 2) performance of serologic testing to detect presence of antibodies is also known, 3) wheth- er and how antibodies confer immunity yet to be proven and 4) false positive and false negative test result phenomenon is also known. They suggested delicate balance to be struck during decision making for antibody testing. ${ }^{19} \mathrm{WHO}$ and other international and national health agencies are waiting for other evidences to unfold.

Testing with RT-PCR is essential in all COVID-19 suspects, if tested and found positive, people can either be isolated in an identified facility or put on strict home isolation ensuring that they are aware of having disease and willing to adhere to protocol instructions. In case of limited resources and if healthcare system is overloaded, limit the visit of non-sick people to health care facilities, so as to minimize the risk of contagion but have a focused strategy for containment. ${ }^{15}$

Data on COVID-19 testing report updated on May 27, 2020 reveals that if testing increases, then it will be known to policy makers and healthcare professionals where the epidemic is? and what next step likely to be taken to contain the pandemic globally or epidemic/outbreak in particular country or particular region, province, city or village of the country ${ }^{20}$ (Figure 1).

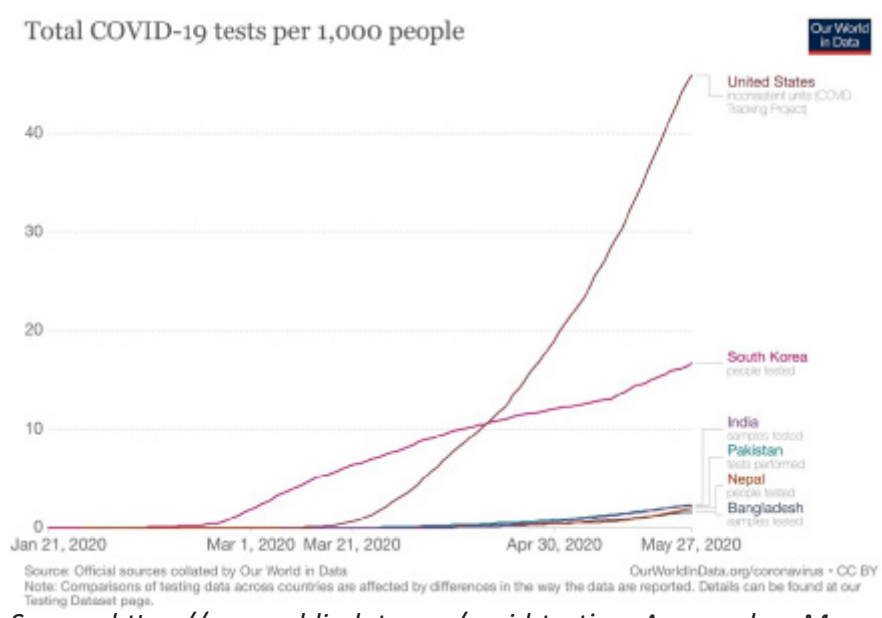

Source: https://ourworldindata.org/covid-testing. Accessed on May 29, 2020

Figure 1: Total COIVD-19 tests per thousand people (Jan 21May 27, 2020) 
Data of USA, South Korea, India, Pakistan, Bangladesh and Nepal is compared as an example with regard to the population, test done and new cases detected (Table 2). South Korea is selected because it slows down the curve while USA have been reporting highest number of cases globally. South Korea has succeeded in flattening the curve with rapid increase in testing. After testing South Korea isolated detected cases and traced contacts and quarantined them in time. The process is continued.

Table 2: Comparison of COVID-19 laboratory test (RT-PCR) data of some countries April 6-May27, 202021-22

\begin{tabular}{|l|c|c|c|c|c|}
\hline \multirow{2}{*}{ Country } & \multirow{2}{*}{ Population } & \multicolumn{2}{c|}{ 6-Apr-20 } & \multicolumn{2}{c|}{ 27-May-20 } \\
\cline { 3 - 6 } & & $\begin{array}{c}\text { Tests/1000 } \\
\text { population }\end{array}$ & $\begin{array}{c}\text { New Cases } \\
\text { Reported }\end{array}$ & $\begin{array}{c}\text { Tests/1000 Cases } \\
\text { population }\end{array}$ & $\begin{array}{c}\text { New } \\
\text { Reported }\end{array}$ \\
\hline USA & 331 million & 5.87 & 375,348 & 16.64 & $1,745,803$ \\
\hline *South Korea & 51 million & 9.11 & 10,284 & 2.35 & 158,086 \\
\hline India & 1380 million & 0.07 & 4,478 & 2.26 & 59,151 \\
\hline Pakistan & 220 million & 0.18 & 3,766 & 1.62 & 38,292 \\
\hline Bangladesh & 164 million & 0.02 & 123 & 2 & 82 \\
\hline Nepal & 29 million & 0.07 & 9 & & 262 \\
\hline
\end{tabular}

\section{*Curve flattens in South Korea ${ }^{2}$}

Data in table 2 clearly shows "with increasing number of RTPCR tests per 1000 population, the greater number of new cases are detected. This provides input to policy maker to relook into their strategy for containment.

\section{CONCLUSION}

In conclusion, countries need to increase the testing for COVID-19. Without widespread testing, it is difficult to know how the pandemic is spreading and how appropriate are our

\section{REFERENCES}

1. COVID-19 Coronavirus Pandemic. Accessed on June 07, 2020 Available at: [LINK]

2. COVID-19 is an emerging, rapidly evolving situation. COVID-19, MERS \& SARS. Available at: [LINK]

3. Peeri NC, Shrestha N, Rahman MS, Zaki R, Tan Z, Bibi S, et al. The SARS, MERS and novel coronavirus (COVID-19) epidemics, the newest and biggest global health threats: what lessons have we learned? Int J Epidemiol.2020. [DOI]

4. Guo $\mathrm{Y}$, Cao $\mathrm{Q}$, Hong Z, TanY, Chen $\mathrm{S}$, Jin $\mathrm{H}$, et al. The origin, transmission and clinical therapies on coronavirus disease 2019 (COVID-19) outbreakan update on the status. Military Med Res. 2020;7: 11. [DOI]

5. Paudel S, Dangal G, Chalise A, Bhandari TR, Dangal O. The Coronavirus Pandemic: What Does the Evidence Show? J Nepal Health Res Councl. 2020;18(1):1-9. [DOI]

6. Wu Z, McGoogan JM. Characteristics of and Important Lessons from the Coronavirus Disease 2019 (COVID-19) Outbreak in China: Summary of a Report of 72314 Cases from the Chinese Center for Disease Control and Prevention. JAMA. 2020;323(13):1239-42. [DOI]

7. Comparing outbreaks. [Internet]. Accessed on April 20, 2020. Available at: [LINK]

8. Watson J, Penny F, Brush JE. Interpreting a covid-19 test result. BMJ 2020;369:m1808. [DOI]

9. RT-PCR and NAAT for COVID-19. Available at: [LINK]

10. Long, Q., Liu, B., Deng, H. et al. Antibody responses to SARS-CoV-2 in patients with COVID-19.Nat Med (2020). [DOI] responses and whether to escalate the responses or continue the same strategy or scale down the ongoing interventions. The tests directly detecting viral RNA like RT-PCR are essential to diagnose the COVID-19 patients and for their subsequent management as to declare the patient recovered and trace the contacts, test and then isolate/quarantine as to prevent further spread of infection. Antibody tests may give detail about the prevalence of a disease in a population at a particular point in time by ascertaining the persons who have developed antibodies against the virus. These tests are useful for surveillance purposes.

11. Deng CX. The global battle against SARS-CoV-2 and COVID-19. Int J Biol Sci. 2020;16(10):1676-7. [DOI]

12. WHO.Laboratory testing for coronavirus disease ("COVID-19)| in suspected human cases: interim guidance, 19 March 2020. [Internet].Accessed on April25, 2020. Available at: [LINK]

13. Petherick A. Developing antibody tests for SARS-CoV-2. The Lancet. April 4, 2020; 395(10230):1101-1102. [PubMed] [DOI] [DOI]

14. Xie C, Jiang L, Huang G, Pu H, Gong B , Lin H, et al. Comparison of different samples for 2019 novel coronavirus detection by nucleic acid amplification tests. Int J Infect Dis. 2020; 93:264-267. [DOI]

15. Tang Y, Schmitz JE, Persing DH, Stratton CW. The Laboratory Diagnosis of COVID-19 Infection: Current Issues and Challenges. J Clin Microbiol. 2020 Apr 3. pii: JCM.00512-20. [Epub ahead of print] [DOI]

16. Infectious Disease Society of America. IDSA COVID-19 Antibody Testing Primer Infectious May 4, 2020. Available at [LINK]

17. World Health Organization. Advice on the use of point-of-care immunodiagnostic tests for COVID-19. Scientific Briefing April 8, 2020. Available at: [LINK]

18. National Testing Guidelines for COVID-19. Ministry of Health and Population Welfare, Government of Nepal June 2, 2020. Available at: [LINK]

19. Weinstein MC, Freedberg KA, Hyle EP, Paltiel AD. Waiting for Certainty on Covid-19 Antibody Tests. N Engl J Med. 2020. [DOI]

20. To test or not to test? Two experts explain COVID-19 testing. Accessed on April 25 2020. Available at: [LINK]

21. Hasell J, Ortiz-Ospina E, Mathieu E, Ritchie H, Beltekian D, Roser M. Data on COVID-19 testing. Accessed on May 29, 2020. Available at: [LINK]

22. Countries in the world by population (2020). Accessed on April 25, 2020 